2010-04-01

\title{
Abuse History and Therapy Participation Among Men and Women in Methadone Maintenance Treatment
}

Alexandria Kunzler

Sasha Mondragon

Amy Welsh

Scott Baldwin

Follow this and additional works at: https://scholarsarchive.byu.edu/fhssconference_studentpub

Part of the Psychology Commons

The Annual Mary Lou Fulton Mentored Research Conference showcases some of the best student research from the College of Family, Home, and Social Sciences. The mentored learning program encourages undergraduate students to participate in hands-on and practical research under the direction of a faculty member. Students create these posters as an aide in presenting the results of their research to the public, faculty, and their peers.

\section{BYU ScholarsArchive Citation}

Kunzler, Alexandria; Mondragon, Sasha; Welsh, Amy; and Baldwin, Scott, "Abuse History and Therapy Participation Among Men and Women in Methadone Maintenance Treatment" (2010). FHSS Mentored Research Conference. 5.

https://scholarsarchive.byu.edu/fhssconference_studentpub/5

This is brought to you for free and open access by the Family, Home, and Social Sciences at BYU ScholarsArchive. It has been accepted for inclusion in FHSS Mentored Research Conference by an authorized administrator of BYU ScholarsArchive. For more information, please contact scholarsarchive@byu.edu, ellen_amatangelo@byu.edu. 


\section{Abuse History and Therapy Participation Among Men and Women in Methadone Maintenance Treatment}

Alexandria Kunzler ${ }^{1}$, Amy Welsh², Sasha Mondragon ${ }^{12}$ and Scott Baldwin, Ph.D. ${ }^{1}$ 1. Department of Psychology, Brigham Young University 2. Project Reality

\section{Abstract}

The differences between men $(N=26)$ and women's $(N=27)$ selfreports of abuse and recorded therapy participation were examined among clients in a methadone maintenance treatment program. Results indicate that women report significantly more abuse. We found no significant difference in therapy participation between men and women.

\section{Introduction}

Several studies have examined the influence of gender on substance abuse treatment. When compared to men, women in substance abuse treatment programs report higher rates of emotional, physical or sexual abuse at some point in their lives (Grella, Scott, Foss, Joshi, \& Hser, 2003). Women in substance abuse treatment programs are more likely to be less engaged in treatment than men (King \& Canada, 2004), have lower treatment retention rates and lower treatment completion rates than men (Arfken, Klein, Menza, \& Schuster, 2001). The purposes of the current study were: 1 . To examine whether differences in self-reports of physical, emotional, sexual abuse or neglect history differ among men and women in treatment, and 2 . To evaluate whether there was a significant difference in the amount of therapy men and women participated in over the course of three months.

Procedure

Participants
Participants consisted of 26 men and 27 women 18 years old or older Participants consisted of 26 men and 27 women 18 years old or older center in the Mountain West.

Method

Each participant was given the General Information Questionnaire which was created for the purposes of this study. The questionnaire consisted of 30 items regarding demographic variables, including the participants' history of physical, emotional, or sexual abuse and neglect. Specifically, participants were asked to report whether they have

experienced physical, emotional, or sexual abuse or neglect in their lifetime. Participants were encouraged to attend individual or group therapy as part of routine substance abuse treatment, but therapy participation was a voluntary component of the clients' treatment. Thus, we were interested in whether therapy participation would differ between men and women. We calculated the amount of time participants spent in therapy over a period of three months. Greater therapy participation is thought to be an indicator of motivation for change and possibly treatment progress.

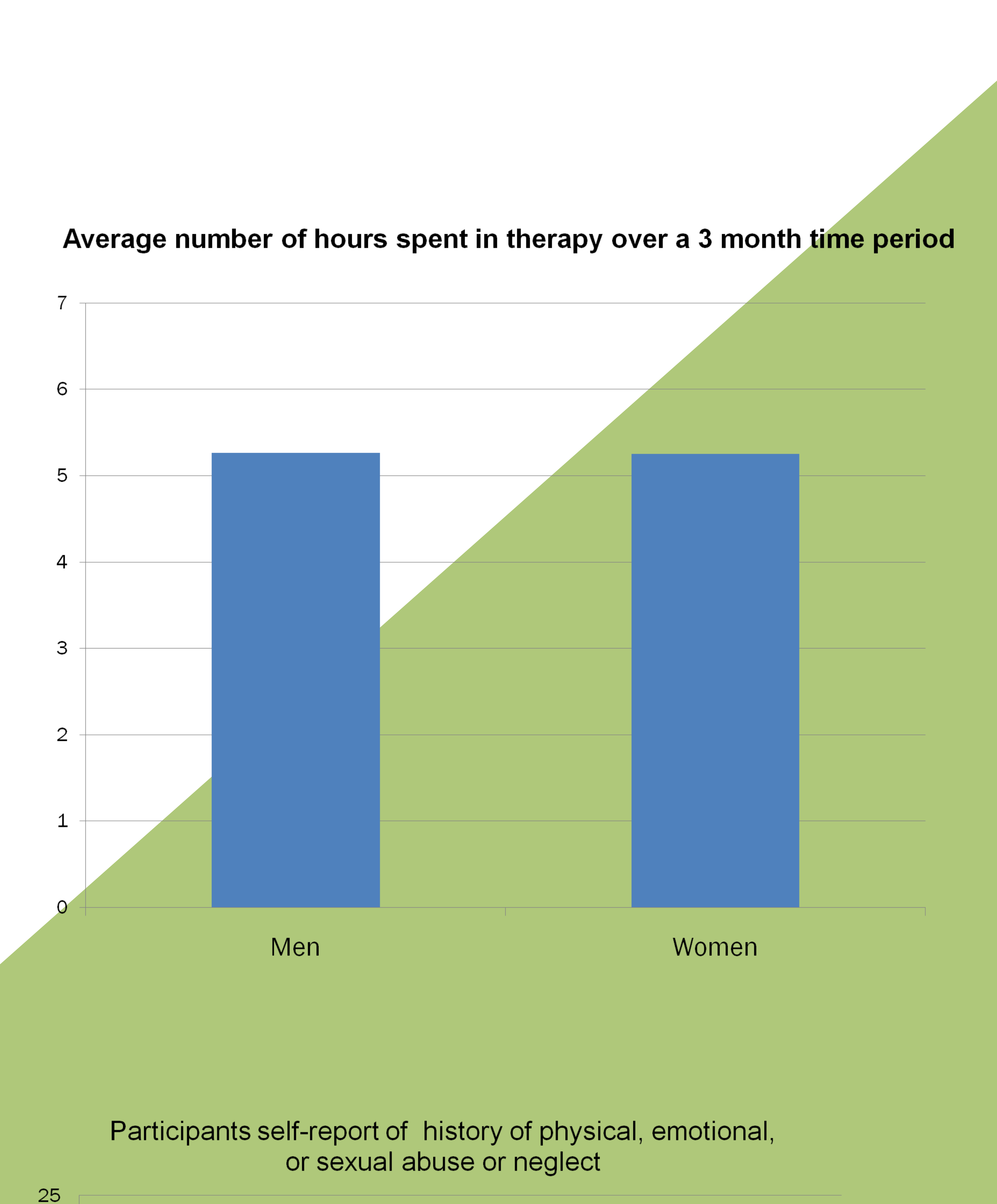

Results

Results of an independent samples t-test indicated that women reported significantly more physical, emotional or sexual abuse or neglect than men $(\mathrm{t}(40)=3.408, p=.002)$. Results of a second independent samples $t$-test indicaled that there is no signilicant difterence in therapy participation between men and women $(t(40)=.010, p=.992)$

\section{Conclusion and Implications}

We found that women in a methadone maintenance program reported significantly more abuse and/or neglect than did men in the program. This finding is similar to that of previous research and adds to the literature base that suggests women in substance abuse treatment likely experience higher rates of abuse and/or neglect than men in treatment. Furthermore, we found that women did not attend more therapy than men. We conclude that

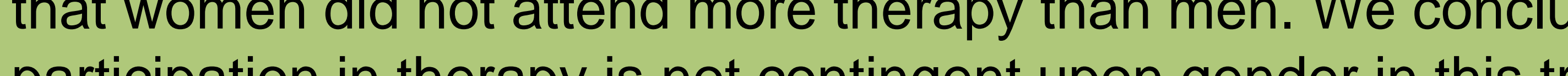
particis It should be norticipants which decreases the power of the study.

\section{References}

Arfken, C.L., Klein, C., Menza, S. and Schuster, C.R. (2001). Gender differences in problem severity at assessment and treatment retention, Journal of Substance Abuse

Grella, C.E., Scott, C.K., Foss, M.A., Joshi, V., and Hser, Y.I. (2003). Gender differences in Drug treatment outcomes among participants in the Chicago Target Cities Study, Evaluation and Program Planning, 26, 297-310.

History of abuse

King, A.C. and Canada, S.A. (2003). Client-related predictors of early treatment drop-out in a substance abuse cilic exclusively employing individual therapy, Journal of Substance Abuse Treatment, 26, 189-195

Acknowledgements

Special thanks and credit to the Women's Research Institute at Brigham Young University for providing the funding for this study 